\title{
GLASS-CERAMIC MATERIALS ON THE LITHIUM DISILICATE BASIS: ACHIEVEMENTS AN D DEVELOPMENT PROSPECTS
}

\author{
Oksana Savvova1, * , Gennadii Voronov ${ }^{1}$, Vitalii Topchyi $^{1}$, Yuliya Smyrnova ${ }^{1}$
}

https://doi.org/10.23939/chcht12.03.391

\begin{abstract}
The current state of developments and the prospects of using glass-ceramics based on lithium disilicate were analyzed. The choice of $\mathrm{R}_{2} \mathrm{O}-\mathrm{RO}-\mathrm{RO}_{2-}$ $\mathrm{R}_{2} \mathrm{O}_{3}-\mathrm{P}_{2} \mathrm{O}_{5}-\mathrm{SiO}_{2}$ system for model glasses was justified. The structure of glasses after heat treatment in connection with their physico-chemical properties was studied. The developed lithiumsilicate glass-ceramic materials were characterized by high performance properties and can be used as transparent armor.
\end{abstract}

Keywords: glass-ceramics, lithiumsilicate glasses, lithium disilicate, high-strength, transparent armor.

\section{Introduction}

Glass-ceramic materials are widely used in many fields of science and technology due to the combination of various physical and chemical properties and performance characteristics inherent in substances in the vitreous and crystalline states. The direction of modern materials science is the synthesis of "intelligent" glass-ceramic materials, which will differ in a number of unique properties. Today, the interest in obtaining new glassceramic materials is explained by the need to ensure the functionality of new generation machines and mechanisms and to develop fundamentally new aspects of their creating. Among these materials, a special place is occupied by glass-ceramic materials based on lithium disilicate. This is due to their high strength characteristics, low weight, manufacturability, and relatively low cost.

In the recent years, there has been an increase in demand for universal materials that are capable of withstanding high-speed mechanical impact (bulletproofing, manufacturing of abrasive tools, etc.) and compete with more expensive known ceramic analogues.

\footnotetext{
${ }^{1}$ National Technical University "Kharkiv Polytechnic Institute"

2, Kyrpychova St., 61002 Kharkiv, Ukraine

*savvova_oksana@ukr.net

(C) Savvova O., Voronov G., Topchyi V., Smyrnova Yu., 2018
}

Most often, the glass-ceramics on the basis of crystal phases of cordierite, anorthite are used for the solution of these problems. But they are no longer able to meet the growing requirements for mechanical strength, hardness and manufacturability. These circumstances have become the reason for the development and synthesis of new compounds of glass-ceramics based on a high-strength compound - lithium disilicate (Table 1).

Glass-ceramics based on lithium disilicate has been successfully used in dentistry for a long time due to its high strength, natural appearance and the possibility of pressing very thin structures (Fig. 1) [1]. The bending strength of such a competitive high-quality dental glassceramics is $450 \mathrm{MPa}$ [2].

N. Suzdal [3] obtained glass-ceramic materials based on lithium meta- and disilicate by two-step technology (Table 2). The developed materials are characterized by high bending strength, hardness and specific electrical resistance. Ballistic tests have confirmed their competitive ability in protecting against LPS (light bullet with steel core) bullets with a mild steel core compared to the used boron carbide. The prospects of their use as insulators have been established.

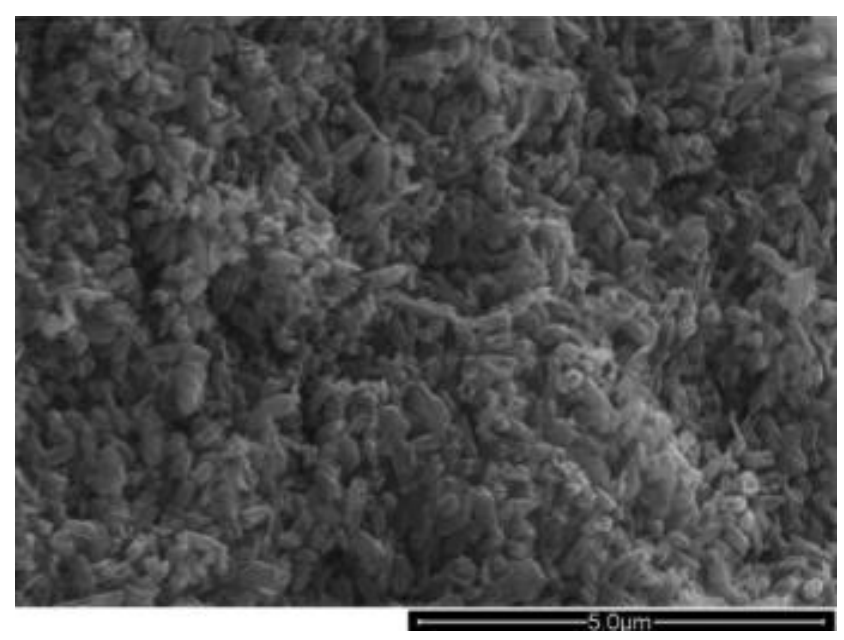

Fig. 1. Structure of glass-ceramics on the lithium disilicate basis 
Lithium disilicate properties

\begin{tabular}{|l|c|}
\hline TCLE, $\alpha_{100-500} \cdot 10^{7}, \mathrm{deg}^{-1}$ & 105 \\
\hline Bending strength, $\mathrm{MPa}$ & 360 \\
\hline Fracture viscosity, $\mathrm{MPa} \cdot \mathrm{m}^{1 / 2}$ & 2.25 \\
\hline Young's modulus, $\mathrm{GPa}$ & 95 \\
\hline Vickers hardness, $\mathrm{MPa}$ & 5800 \\
\hline Chemical resistance, $\mu \mathrm{g} / \mathrm{cm}^{2}$ & 40 \\
\hline Crystallization temperature, $\mathrm{K}$ & 1113 \\
\hline Melting point, $\mathrm{K}$ & 1305 \\
\hline Density, g/cm & 2.454 \\
\hline Refractive indices Ng & 1.558 \\
$\mathrm{~Np}$ & 1.547 \\
$\mathrm{Ng}-\mathrm{Np}$ & 0.011 \\
\hline
\end{tabular}

Table 2

Known methods of obtaining and properties of glass-ceramics based on lithium disilicate

\begin{tabular}{|c|c|c|c|c|c|c|c|}
\hline \multirow{2}{*}{ Application } & \multirow{2}{*}{ Dental material [2] } & \multicolumn{6}{|c|}{ Multifunctional materials } \\
\hline & & [3] & [4] & {$[5]$} & {$[6]$} & [7] & [9] \\
\hline \multicolumn{8}{|c|}{ Glass-melting temperature, $\mathrm{K}$} \\
\hline & 1773 & $1473-1523$ & $1573-1623$ & $1523-1623$ & 1823 & - & $1673-1773$ \\
\hline \multicolumn{8}{|c|}{ Heat treatment temperature $(\mathrm{K})$, time } \\
\hline Annealing & 833 & - & $673-693$ & $663-693$ & 783 & - & $723-773$ \\
\hline I stage & $\begin{array}{l}873-1023, \\
10-120 \mathrm{~min}\end{array}$ & $\begin{array}{c}753-773, \\
5 \mathrm{~h}\end{array}$ & $\begin{array}{c}753-793, \\
2-3 \mathrm{~h}\end{array}$ & $\begin{array}{c}753-793 \\
1-3 \mathrm{~h}\end{array}$ & $\begin{array}{c}753-803, \\
1-24 \mathrm{~h}\end{array}$ & $\begin{array}{c}863-883 \\
10 \mathrm{~h}\end{array}$ & $\begin{array}{c}873-1083, \\
15 \mathrm{~min}-4 \mathrm{~h}\end{array}$ \\
\hline II stage & $\begin{array}{c}1073-1223, \\
3-15 \mathrm{~min}\end{array}$ & $\begin{array}{c}\text { 953-993, } \\
1.5 \mathrm{~h}\end{array}$ & $\begin{array}{c}953-993, \\
1-2 \mathrm{~h}\end{array}$ & $853-893,0.5-10 \mathrm{~h}$ & $\begin{array}{c}953-998, \\
30 \mathrm{~min}-24 \mathrm{~h}\end{array}$ & $\begin{array}{c}1043-1273 \\
2 \mathrm{~h}\end{array}$ & $\begin{array}{l}948-1273, \\
15 \min -4 \mathrm{~h}\end{array}$ \\
\hline III stage & - & - & - & $\begin{array}{c}943-1003 \\
1-3 \mathrm{~h}\end{array}$ & $\begin{array}{c}1103-1143 \\
5 \mathrm{~min}-5 \mathrm{~h}\end{array}$ & - & - \\
\hline \multicolumn{8}{|c|}{ Properties } \\
\hline$\rho, \mathrm{g} / \mathrm{cm}^{3}$ & - & $2.36-2.47$ & $2.39-2.45$ & $2.36-2.46$ & $2.45-2.5$ & $2.53-2.73$ & 2.45 \\
\hline$\sigma_{\text {bend }}, \mathrm{MPa}$ & $300-450$ & $270-380$ & $380-400$ & $343-441$ & - & 119 & - \\
\hline$\alpha \cdot 10^{7},{ }^{\circ} \mathrm{C}^{-1}$ & - & - & $106-114$ & $100-120$ & 125 & - & $65-80$ \\
\hline Hardness, $\mathrm{MPa}$ & - & $\begin{array}{c}H V= \\
7300-8700\end{array}$ & - & - & $\begin{array}{c}H K= \\
505-635\end{array}$ & $\begin{array}{c}H V= \\
6400-11000\end{array}$ & $H K=680$ \\
\hline$K_{l C}, \mathrm{MPa} \cdot \mathrm{m}^{1 / 2}$ & - & $1.6-1.8$ & - & - & - & $1.7-2.4$ & - \\
\hline$\rho_{v}, \Omega \cdot \mathrm{cm}$ & - & $10^{14}$ & - & - & & - & - \\
\hline
\end{tabular}

Developed by V. Khalilev et al. [4] a high-strength glass-ceramics based on the lithium-silicate glass with content of lithium disilicate and silica of $0.2-0.4 \mu \mathrm{m}$ in size is characterized by low density combined with high mechanical strength, which makes it possible to use the developed material under extreme loads. Hydrolytic resistance of the material corresponds to Class I. Ballistic tests showed that the limit of the back strength of the samples based on the developed glass-ceramics is 5-7\% higher than that of boron carbide samples. Considering the complex technology of obtaining ceramics based on boron carbide, its high weight and high cost, the prospects of using the developed glass-ceramics under conditions of extreme loads, as cheaper and more technological, have been confirmed.

$\mathrm{Yu}$. Merkulov [5] developed a glass-ceramic material in the $\mathrm{Li}_{2} \mathrm{O}-\mathrm{Na}_{2} \mathrm{O}-\mathrm{K}_{2} \mathrm{O}-\mathrm{ZnO}-\mathrm{MnO}_{2}-\mathrm{LiF}-\mathrm{CaF}_{2}-$ $\mathrm{P}_{2} \mathrm{O}_{5}-\mathrm{SiO}_{2}$ system, characterized by high strength and operational parameters as well as constructions on its basis for protection from impact and abrasive wear. B. Rudoi [6] created a high-strength glass-ceramic material based on lithium disilicate, cristobalite and spinel with high ballistic resistance. However, the temperature coefficient of linear expansion of the developed glass- 
ceramic materials does not allow to ensure the thermal stability of the main properties and linear dimensions of the material when the temperature changes. J. Darrant $e t$ al. [7] proposed a method for obtaining a transparent glass-ceramic armor with high mechanical strength for viewing windows, vehicles, and windscreen vitrification of helicopters. To achieve a high density of crystallization centers $>10^{20}$ per cubic meter, the heat treatment of the initial glass during the nucleation stage is advantageously carried out in the range of $793-853 \mathrm{~K}$ for $10-170 \mathrm{~h}$. The glass-ceramics obtained by the improved regime (stage I $863 \mathrm{~K}, 2 \mathrm{~h}$; stage II $-1023 \mathrm{~K}, 2$ h) [8], are characterized by the following property values: $\rho=2.53 \mathrm{~g} / \mathrm{cm}^{3}$, $\sigma_{\text {bend }}=167 \mathrm{MPa}, H V=8700 \mathrm{MPa}, E=101 \mathrm{GPa}, \mathrm{K}_{l C}=$ $=2.1 \mathrm{MPa} \mathrm{m}^{1 / 2}$. However, the developed materials [7] differ by rather long stages of heat treatment at the stage of nucleation of crystals, which affects their manufacturability and cost. If the time of heat treatment decreases, these materials [8] will have insufficient values of hardness and fracture toughness for their use in conditions of high-speed mechanical action.

A composition of high-strength glass-ceramics of polyfunctional purpose is known, containing as a crystalline phase $30-65 \mathrm{wt} \%$ of lithium disilicate and 20 $60 \mathrm{wt} \%$ of $\beta$-spodumene [9]. The developed glassceramics due to the features of the structure is characterized by low density indices. However, the hardness values do not allow the use of these materials as high-strength and fire-resistant for armored protection elements.

Therefore, the important task today is to increase the level of protection of special equipment, which is operated under conditions of high temperatures and mechanical loads, via development of compositions of prospective lithium silicate glasses and production of lightweight glass-ceramic armor panels on their basis with high optical, thermal and mechanical properties.

The aim of this work is the development of highstrength technological glass-ceramic lithium silicate materials for protection elements of special equipment.

\section{Experimental}

\subsection{Development of a Methodological Approach for the Production of Transparent High-Strength Glass- Ceramic Materials}

The problem of obtaining material for reliable armor protection calls for the development of a methodological approach, which consists in determining the set of requirements for the material and its functional role.

The main functional requirements for transparent armor include high explosive and one- and multi-impact ballistic resistance and transparency in the visible and infrared regions of the spectrum (Table 3). However, the key aspect in the choice of constituent materials is strict compliance with the requirements for design and application $[10,11]$.

The combination of these properties of glassceramic materials as transparent armor elements can be achieved by designing the necessary composition of the initial glass and forming of nano- and microstructures of high-strength transparent crystalline compounds in the process of low-temperature heat treatment due to:

- occurrence of fine volume crystallization of glass at a two-stage low-temperature $(<1123 \mathrm{~K})$ and short-term $(<1 \mathrm{~h})$ heat treatment mode due to:

- design of compositions based on lithium silicate glasses in the region of metastable liquation and crystallization of lithium disilicate;

- providing the formation of stoichiometric groups $\left[\mathrm{SiO}_{4}\right]$ at a mass ratio of $\mathrm{SiO}_{2} / \mathrm{Li}_{2} \mathrm{O}=4.0$ to obtain a glass melt with a viscosity of $10^{7}-10^{8} \mathrm{~Pa} \cdot \mathrm{s}$ for crystallization of lithium disilicate;

- use of crystallization catalysts $\mathrm{ZrO}_{2}$ and $\mathrm{CeO}_{2}$;

- formation of a high-strength, elastic, optical, and radio transparent structure of the material due to:

- high velocity of the shock wave in the armor material $(6.0-6.4 \mathrm{~km} / \mathrm{s})$;

- the specific content of crystalline (no more than $70 \%)$ and glass phase;

- the particle size smaller than the wavelength in the visible part of the spectrum;

- the correspondence between the refractive indices of the crystalline and the glass phase;

- small optical scattering and low atomic absorption in the visible region;

- use of $\mathrm{Sb}_{2} \mathrm{O}_{3}$ and $\mathrm{CeO}_{2}$ as fining agents.

\subsection{Methods of Analysis}

Physico-chemical methods for studying the processes occurring in the model glasses during heat treatment were used, in particular, differential thermal (DTA), gradient-thermal, petrographic, and dilatometric analyzes. Values of mechanical properties were obtained with the help of PMT-3 and TMV-1000 hardness testers, and a static-method tester for measuring the elasticity modulus. 
Values of criteria for glass-ceramic materials according to national and international standards

\begin{tabular}{|c|c|c|}
\hline Criteria & Value & Standards \\
\hline \multicolumn{3}{|l|}{ Properties } \\
\hline Density, $\mathrm{g} / \mathrm{cm}^{3}$ & $2.3-2.45$ & GOST 9553-74 \\
\hline \multicolumn{3}{|c|}{ Mechanical } \\
\hline Fracture viscosity, $\mathrm{MPa} \cdot \mathrm{m}^{1 / 2}$ & $3.0-3.5$ & GOST 25.506-85 \\
\hline Impact strength, $\mathrm{kJ} / \mathrm{m}^{2}$ & $5.0-6.0$ & GOST 11067-2013 (EN1288-1:2000) \\
\hline Bending strength, MPa & $400-500$ & GOST 32281.1-2013 \\
\hline Young's modulus, GPa & $100-120$ & GOST 9900-2013 \\
\hline Hardness & & GOST ISO 9385 \\
\hline Knoop $H K$ & $800-1000$ & \\
\hline Vickers $H V, \mathrm{MPa}$ & $7000-8500$ & \\
\hline microhardness, $\mathrm{MPa}$ & $7000-8500$ & GOST 9450-76 \\
\hline Attrition, $\mathrm{g} / \mathrm{cm}^{2}$ & $0.004-0.03$ & GOST 27180-86 \\
\hline Abrasion resistance on reduced visibility $\mathrm{T}_{\mathrm{d}} / \mathrm{T}_{\mathrm{t}}, \%$ & $<2$ & GOST 32565-2013 \\
\hline \multicolumn{3}{|l|}{ 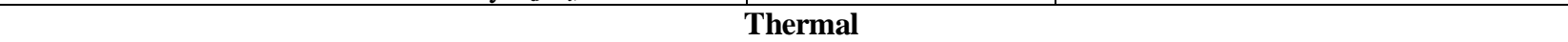 } \\
\hline TCLE, $\alpha_{100-500} \cdot 10^{7}, \mathrm{deg}^{-1}$ & $<80$ & GOST 10978-2014 \\
\hline Fire-resistance & RE45(h)-RE80(h) & GOST 33000-2014 \\
\hline \multicolumn{3}{|c|}{ Electrical } \\
\hline Dielectric constant, $25^{\circ} \mathrm{C}, f=10^{10} \mathrm{~Hz}$ & $5.6-8.3$ & GOST 27496.1-87 \\
\hline Dielectric loss tangent, $25^{\circ} \mathrm{C}, f=10^{10} \mathrm{~Hz}$ & $0.0005-0.02$ & GOST 27496.1-87 \\
\hline \multicolumn{3}{|c|}{ Optical } \\
\hline Optical transmission coefficient $(400-700 \mathrm{~nm})$ & $0.7-0.8$ & GOST 27902-88 \\
\hline \multicolumn{3}{|c|}{ Armor resistance } \\
\hline Explosion resistance, class & ER2-ER4 & GOST 13541-2013 \\
\hline Bullet resistance, class & Br3-Br6 & GOST 32566-2013 \\
\hline Protection level of composite armor element & III & STANAG 4569 \\
\hline Cost, USD/kg & less than 150 & \\
\hline
\end{tabular}

\subsection{Development of Compositions of Lithium Silicate Glasses for the Transparent Glass-Ceramic Materials}

Preliminary investigations of the mechanism of crystallization of lithium silicate glasses SL1, SL2, SL3, SL4, SL5, and SL6 under heat treatment allowed us to establish that glasses with $\mathrm{SiO}_{2} / \mathrm{Li}_{2} \mathrm{O}=4.0$ ratio are characterized by a volume-crystallized fine structure. The crystalline phase are lithium disilicate and $\beta$-spodumene in the amount of $80 \mathrm{vol} \%$, that allows to ensure high mechanical properties of the material [12]. However, the developed glass-ceramics differed in inadequate transparency in the wavelength range of the visible part of the spectrum. Further researches were focused on developing optically transparent high-strength glassceramic materials based on lithium silicate glasses.

$\mathrm{R}_{2} \mathrm{O}-\mathrm{RO}-\mathrm{RO}_{2}-\mathrm{R}_{2} \mathrm{O}_{3}-\mathrm{P}_{2} \mathrm{O}_{5}-\mathrm{SiO}_{2}$ was taken as a glass-forming system and the composition range of the initial samples was chosen, which was in the following concentration limits, mas \%: $\mathrm{R}_{2} \mathrm{O} \Sigma\left(\mathrm{K}_{2} \mathrm{O}, \mathrm{Li}_{2} \mathrm{O}\right)-15.0-$ 17.0; $\mathrm{RO} \Sigma(\mathrm{CaO}, \mathrm{SrO}, \mathrm{MgO}, \mathrm{ZnO})-2,5-8,0 ; \mathrm{ZrO}_{2}-$
0 - 12.0; $\mathrm{CeO}_{2} 0-0.5 ; \mathrm{R}_{2} \mathrm{O}_{3}-\Sigma\left(\mathrm{Al}_{2} \mathrm{O}_{3}, \mathrm{~B}_{2} \mathrm{O}_{3}\right)-3.0-$ 9.0; $\mathrm{Sb}_{2} \mathrm{O}_{3}-0-1.5 ; \mathrm{P}_{2} \mathrm{O}_{5}-0-3.0 ; \mathrm{SiO}_{2}-60.0-67.0$. It was used to synthesize model glasses of the SL series with marking SL7, SL8, SL9, SL10, SL11, and SL12 with the ratio $\mathrm{SiO}_{2} / \mathrm{Li}_{2} \mathrm{O}=4.0$ (Table 4). The compositions were melted at 1523-1623 K under identical conditions in corundum crucibles, followed by quenching on a metal plate. The resulting glasses were transparent (Fig. 2).

The presence of $\mathrm{K}_{2} \mathrm{O}$ in experimental glasses makes it possible to significantly reduce their melting and heat treatment temperatures, and to reduce their density together with $\mathrm{B}_{2} \mathrm{O}_{3}$, which is an important condition for obtaining technological lightweight glass-ceramic materials. The role of crystallization catalyst $\mathrm{ZrO}_{2}$ in the structure of materials is to accelerate the appearance of the first crystalline phase, which precipitates on their nucleators with the formation of a fine structure. Because of the fact that the crystallization catalysts mainly remain in the amorphous phase, its refractive index is increased. The correspondence between the refractive indices of the amorphous and crystalline phases, together with the presence of fine particles of lithium disilicate in the structure, will ensure the light transmission, chemical 
stability and high strength properties of the material. In this case, the introduction of $\mathrm{ZrO}_{2}$ in the amount of 10.0 $12.0 \%$ allows to substantially reduce the TCLE of the developed material, despite its high values for lithium disilicate (Table 1).

$\mathrm{P}_{2} \mathrm{O}_{5}$ was introduced into the composition of the initial glasses to form a fine interlocked structure by liquation mechanism. The growth in the number of nuclei formed in the first stage of heat treatment makes it possible to lower the temperature and time of exposure in the second stage while maintaining the phase composition and the degree of crystallinity of the glass-ceramics. The presence of $\mathrm{P}_{2} \mathrm{O}_{5}$ in the structure of model glasses, according to Ref. [13], will decrease the deformation and stresses that occur upon absorbing the impact energy. The introduction of $\mathrm{CeO}_{2}$ will promote the formation of crystalline phases in the region of lower temperatures, and will also provide the transparency of the glass-ceramic materials.

Modifying additives $\mathrm{ZnO}, \mathrm{SrO}, \mathrm{MgO}$, andCaO are introduced to reduce the viscosity of the glass-forming melt during melting and control of the thermal characteristics of the residual glass phase and the crystalline phase.

In the presence of antimony oxide, the viscosity of the melt also decreases and the conditions for the glass refining improve [2]. For glass-ceramics with the degree of crystallinity not less than $40 \mathrm{vol} \%$, considering the high propensity of antimony oxide in glass formation, the structure of the residual glass phase is formed with the participation of silicon, phosphorus and antimony oxides. Since the strength of the $\mathrm{Sb}-\mathrm{O}$ bonds is much less than that of other glass formers, the elastic properties of the residual glass phase decrease and the nanocrystals that have formed are located in a more ductile matrix. These circumstances cause a greater stability of the thermal coefficient of linear expansion of the glass-ceramics in a wide range of temperatures.

The factor $\Psi_{\mathrm{A} / \mathrm{B}}$, the numerical values of which for all compositions are greater than one (Table 4), which indicates the overwhelming presence of $\left[\mathrm{BO}_{4}\right]$ and $\left[\mathrm{AlO}_{4}\right]$ tetrahedra in the glass structure was calculated for predicting the structure of model glasses. For all model glasses, the value of $K_{c r}$ is more than 3.5, which is testimony to a sufficient total content of modifying oxides in the glass melt to form sybotaxic groups, which are nuclei of crystalline phases; the value $K_{t r}>2.1$ and indicates favorable conditions for the nucleation of glass melt upon quenching and crystal growth during heat treatment.

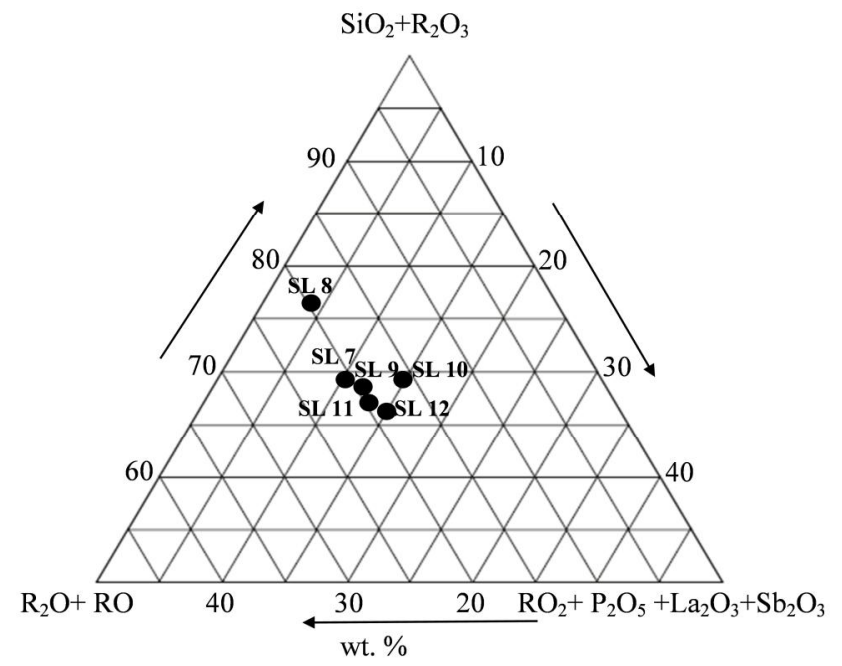

Fig. 2. Experimental pseudo-ternary system $\Sigma \mathrm{R}_{2} \mathrm{O}, \mathrm{RO}-\Sigma \mathrm{SiO}_{2}, \mathrm{R}_{2} \mathrm{O}_{3}-\Sigma \mathrm{RO}_{2}$, $\mathrm{P}_{2} \mathrm{O}_{5}, \mathrm{La}_{2} \mathrm{O}_{3}, \mathrm{Sb}_{2} \mathrm{O}_{3}$

Table 4

\section{Differences in chemical composition and calculated values of the factors characterizing the structure}

\begin{tabular}{|l|c|c|c|c|c|c|}
\hline \multirow{2}{*}{ Differences in chemical composition, wt.\% and calculated factors } & \multicolumn{7}{|c|}{ Glass marking } \\
\cline { 2 - 7 } & SL7 & SL8 & SL9 & SL10 & SL11 & SL12 \\
\hline $\mathrm{SiO}_{2} / \mathrm{Li}_{2} \mathrm{O}$ & 4.0 & 4.0 & 4.0 & 4.0 & 4.0 & 4.0 \\
\hline $\mathrm{ZrO}_{2}$ & 7.0 & - & 10.0 & 12.0 & 10.0 & 10.0 \\
\hline $\mathrm{RO}$ & 6.0 & 8.0 & 2.5 & - & 4.0 & 4.0 \\
\hline Degree of connectedness of silicon-oxygen framework of glass $f_{\mathrm{Si}}$ & 0.32 & 0.35 & 0.35 & 0.32 & 0.34 & 0.33 \\
\hline $\begin{array}{l}\text { Structural factor, which determine the coordination state of boron } \\
\text { and aluminum in framework of glass } \Psi_{\mathrm{A} / \mathrm{B}}\end{array}$ & 2.35 & 2.57 & - & 1.98 & 5.08 & 4.81 \\
\hline Coefficient of transparency $K_{t r}$ & 2.49 & 2.38 & 2.6 & 2.51 & 2.6 & 2.6 \\
\hline Coefficient of crystallinity $K_{c r}$ & 8.56 & 9.02 & 38.28 & 13.01 & 16.71 & 15.98 \\
\hline
\end{tabular}




\section{Results and Discussion}

\subsection{Structure Formation and Phase Composition of $\mathbf{G}$ lass $\mathbf{M}$ aterials during their Heat Treatment}

According to the data of XRD, model glasses are $\mathrm{X}$-ray amorphous after melting. After a one-stage exposure in a gradient furnace, the experimental glass materials are characterized by a fine structure with a crystalline phase content of $40-50 \mathrm{vol} \%$ (Fig. 3). The crystallization of model glasses SL7, SL9, SL10, SL11 and SL12 begins in the temperature range of 873-923 K and manifests as opalescence to temperatures of 1073$1173 \mathrm{~K}$. For glass SL8 the temperature of the beginning of crystallization and opalescence is shifted to $973 \mathrm{~K}$, which is associated with a significant content of refractory oxides $(\mathrm{MgO}+\mathrm{CaO}=8.0 \mathrm{wt} \%)$. The total content of $\mathrm{MgO}$ and $\mathrm{CaO}$ in the amount of $4.0 \mathrm{wt} \%$ is the cause of the transparency of SL7 glass only at $1173 \mathrm{~K}$. For glass $\mathrm{SL} 11$ at $\mathrm{MgO}+\mathrm{CaO}=3.0 \mathrm{wt} \%$, the area of appearance of optically transparent glass shifts to $1123 \mathrm{~K}$, and for SL12 glass - to $1073 \mathrm{~K}$, due to the substitution of $1.0 \mathrm{wt} \%$ of $\mathrm{MgO}$ and $\mathrm{CaO}$ by $1.0 \mathrm{wt} \%$ of $\mathrm{SrO}$, and also when the content in both glasses is $1.0 \mathrm{wt} \%$ of $\mathrm{ZnO}$. The optical transparency of the SL7, SL11 and SL12 glasses upon the thermal treatment is affected by the presence of 0.5 wt $\% \mathrm{CeO}_{2}$, and for SL12 also by 1.5 wt $\% \mathrm{Sb}_{2} \mathrm{O}_{3}$. An increase of the $\mathrm{SiO}_{2}$ content in $\mathrm{SL} 9$ and $\mathrm{ZrO}_{2}$ in $\mathrm{SL} 10$ due to the withdrawal from the composition of $\mathrm{MgO}$ and $\mathrm{CaO}$ influences on their opalescent character and the increase of the crystallization ability to $50 \mathrm{vol} \%$.

Gradient-thermal and petrographic analysis made it possible to establish in all experimental glasses the presence of a crystalline phase of lithium metasilicate at 923-973 K, which upon further increase in temperature to $1023-1123 \mathrm{~K}$ is recrystallized into lithium disilicate. The only exception is a glass-ceramic material based on SL10 glass, for which only lithium metasilicate crystallizes in a given regime of single-stage heat treatment. For SL8 glass at $1173 \mathrm{~K}$, in addition to the main crystalline phase (40 vol \%), an insignificant content of mullite (10 vol \%) is observed, which positively influences the mechanical and thermal properties of the material based on it. The content of the crystalline phase of lithium metasilicate and lithium disilicate is about $45-50$ vol \% can adversely affect the thermal properties of materials based on SL10, SL7, and SL9, respectively. The presence of $\beta$-spodumene
( $5 \mathrm{vol} \%$ ) in the phase composition of SL12 glass-based materials will provide thermal and mechanical properties at a certain level.

According to the DTA data for model glasses of the SL series, the temperature and the glass transition interval are determined by their fusible properties and is 723-873 K (Fig. 4). The endo-effect observed for these glasses in the temperature range of $603-673 \mathrm{~K}$ is connected with the removal of residual stresses. In general, high and narrow peaks of exo-effects for experimental glasses may indicate the formation of a fine structure followed by volume crystallization upon increasing temperature. The proximity of the first exoeffect to the endo-effect is related to the glass material crystallization at its high viscosity near the softening point, which allows to suggest that the samples ceramization will take place without its deformation.

A high peak of the exo-effect for the experimental glasses of SL8, SL10 and SL12 at 923, 953 and $903 \mathrm{~K}$, respectively, is observed with considerable intensity, which corresponds to the crystallization of lithium metasilicate and a slight peak of $\beta$-quartz at the temperatures of 1103, 1093 and $1063 \mathrm{~K}$, which are recrystallized into lithium disilicate at the temperatures above $1123 \mathrm{~K}$. For glass SL8 the crystallization of mullite is observed in the temperature range of $1143-1233 \mathrm{~K}$. The displacement of crystallization temperatures for SL10 and SL12 glasses to lower temperatures is associated with a decrease in the content of refractory components of silicon, magnesium and zirconium oxides.

The obtained glass-ceramic materials of the SL series by glass technology under conditions of lowtemperature heat treatment (annealing at $723 \mathrm{~K}, 30 \mathrm{~min}$; stage I 873-953 K, $30 \mathrm{~min}$; II stage $1123-1233 \mathrm{~K}$, 5-10 min) (Table 5) are characterized by a volume fine structure with the presence of the main crystalline phase of lithium disilicate (glass-ceramic materials SL7, SL8, SL9, SL11, and SL12) and lithium metasilicate (SL7, SL8 and SL10) and $\beta$-spodumene (glass-ceramic material SL12) or mullite (glass-ceramic material SL8) with the total content of 50-60 vol \%.

The formation of strength, ceramized structure in SL8, SL9, SL11 and SL12 glasses by low-temperature short-term crystallization with high-strength crystalline phases of lithium disilicate, mullite and $\beta$-spodumene ensures high mechanical and thermal properties of glassceramic materials based on them at simultaneously reduced density (Table 5). 


\begin{tabular}{|c|c|c|c|c|c|c|}
\hline \multirow{2}{*}{$\mathrm{T}, \mathrm{K}$} & \multicolumn{6}{|c|}{ Marking } \\
\hline & SL7 & SL8 & SL9 & SL10 & SL11 & SL12 \\
\hline 873 & & & & & & \\
\hline 923 & & & & & & \\
\hline 973 & & & & & & \\
\hline 1023 & & & & & & \\
\hline 1073 & & & & & & 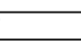 \\
\hline 1123 & 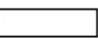 & & & & & \\
\hline 1173 & & & & & & \\
\hline
\end{tabular}

a)

$\square$ - transparent; $\square$ - opalescent

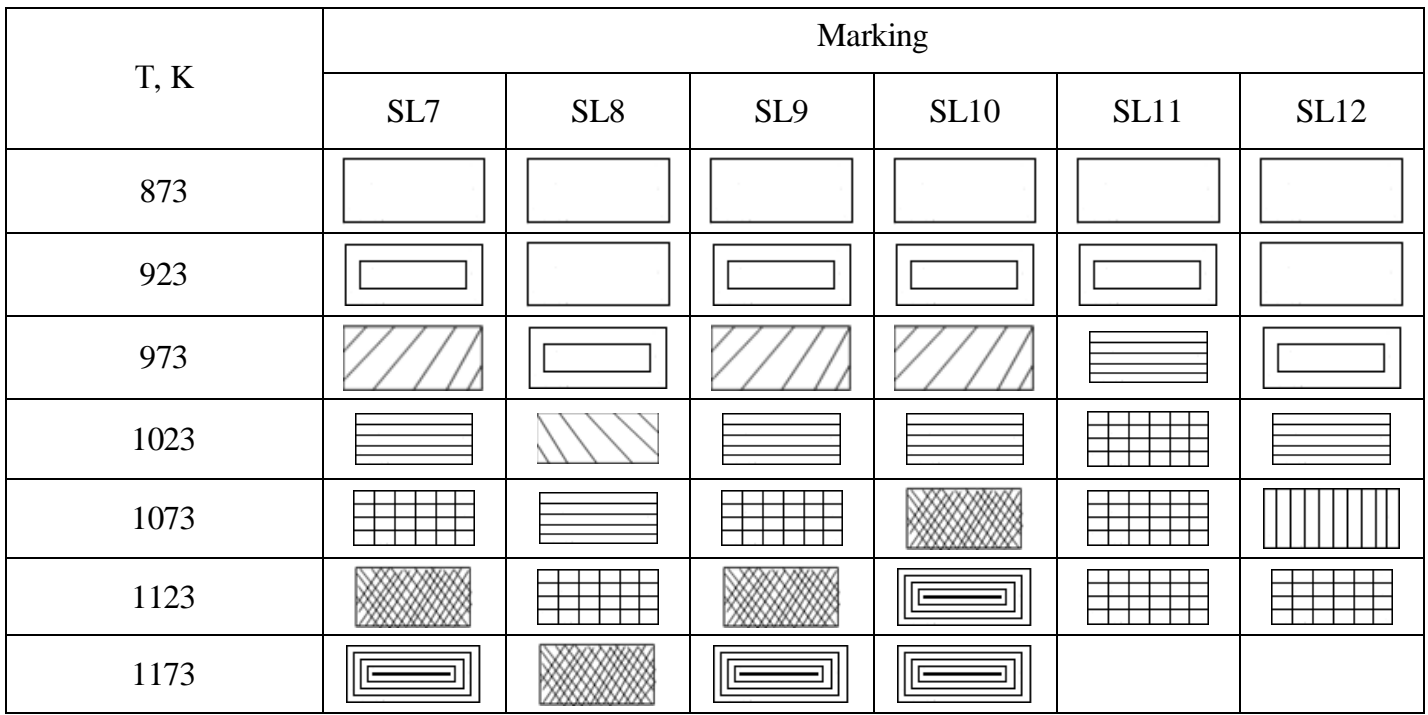

b)

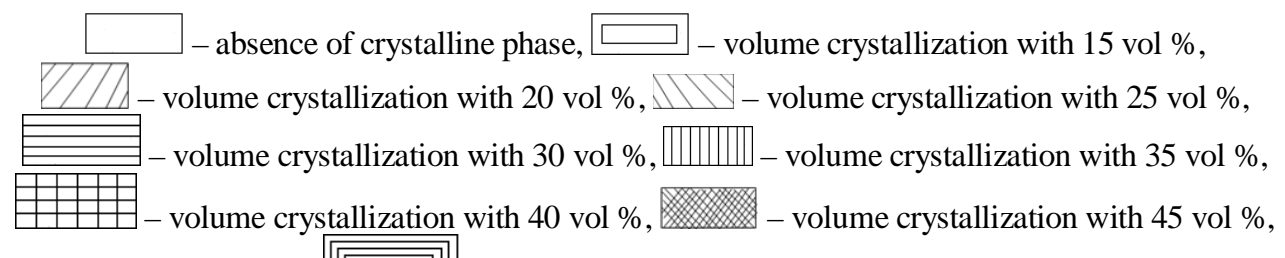

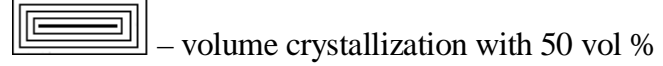

Fig. 3. Optical transparency and crystallization ability of experimental glasses of the SL series during heat treatment by the gradient-thermal analysis method 
Heat treatment parameters of experimental glasses and properties of the SL series glass-ceramic materials on their basis

\begin{tabular}{|c|c|c|c|c|c|c|c|}
\hline \multirow{2}{*}{$\begin{array}{c}\text { Experimental } \\
\text { materials }\end{array}$} & \multicolumn{3}{|c|}{ Heat treatment parameters } & \multicolumn{4}{c|}{ Properties } \\
\cline { 2 - 8 } & $\begin{array}{c}\text { Tann., K/ } \\
\text { time, min }\end{array}$ & $\begin{array}{c}T \text { I st., K/ } \\
\text { time, min }\end{array}$ & $\begin{array}{c}T \text { II st., K/ } \\
\text { time, min }\end{array}$ & $\alpha \cdot 10^{7}, \mathrm{deg}$. & $H V, \mathrm{GPa}$ & $\begin{array}{c}K_{l C}, \\
\mathrm{MPa}^{-1 / 2}\end{array}$ & $\rho, \mathrm{g} / \mathrm{cm}^{3}$ \\
\hline SL 7 & $723 / 30$ & $873 / 30$ & $1173 / 10$ & 95.0 & 7.40 & 2.60 & 2.35 \\
\hline SL 8 & $723 / 30$ & $953 / 30$ & $1233 / 10$ & 67.3 & 8.60 & 3.00 & 2.35 \\
\hline SL 9 & $723 / 30$ & $873 / 30$ & $1173 / 10$ & 90.0 & 8.82 & 3.15 & 2.40 \\
\hline SL 10 & $723 / 30$ & $923 / 30$ & $1153 / 10$ & 88.0 & 7.60 & 2.50 & 2.39 \\
\hline SL 11 & $723 / 30$ & $873 / 30$ & $1123 / 5$ & 70.0 & 8.50 & 3.00 & 2.39 \\
\hline SL 12 & $723 / 30$ & $903 / 30$ & $1123 / 5$ & 62.5 & 8.74 & 3.10 & 2.38 \\
\hline
\end{tabular}

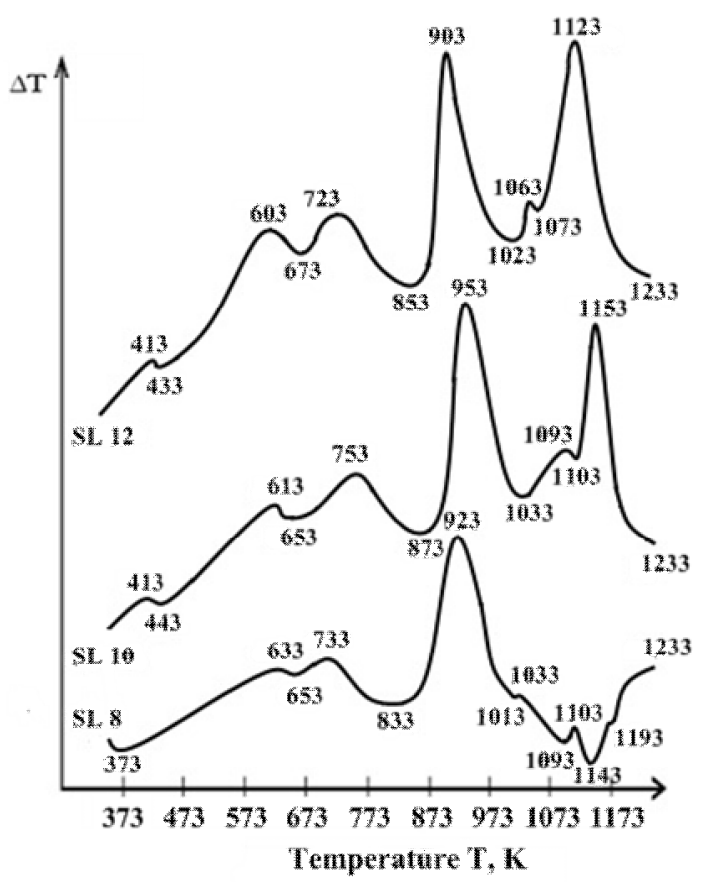

Fig. 4. Thermograms of the SL series model glasses

The value of the light transmittance in the visible part of the spectrum $(400-700 \mathrm{~nm})$ for glass-ceramic material SL12 synthesized under conditions of lowtemperature short-term heat treatment is 0.72 . This fact confirms the possibility of using it as a basis for obtaining transparent armor to protect optical devices from highspeed mechanical impact.

\section{Conclusions}

After analysis of accumulated experience in the area of creating high-strength glass-ceramic materials based on lithium disilicate, the prospects for their use as transparent armor materials for the protection of special equipment have been established. A methodological approach to obtaining protective transparent high-strength glass-ceramic materials has been developed, which consists in providing high ballistic stability and transparency in the visible spectral range due to the fine volume crystallization of glass with the formation of highstrength crystalline phases of lithium disilicate $\approx 50 \mathrm{vol} \%$ with crystal size $\leq 0.4 \mu \mathrm{m}$.

The choice of the initial lithium silicate system was substantiated and the compositions of model glasses were melted at $1523-1623 \mathrm{~K}$.

The factors that determine the formation of a fine volume crystallized structure under conditions of lowtemperature two-stage thermal treatment (annealing $723 \mathrm{~K}, 30 \mathrm{~min}$; stage I $903 \mathrm{~K}, 30 \mathrm{~min}$; stage II $1123 \mathrm{~K}$, $5 \mathrm{~min}$ ) were established. In particular, the ratio of phaseforming oxides is $\mathrm{Li}_{2} \mathrm{O} / \mathrm{SiO}_{2}=4.0$ and type and quantity of catalysts $\mathrm{ZnO}, \mathrm{P}_{2} \mathrm{O}_{5}$, and $\mathrm{ZrO}_{2}$, fining agents $\mathrm{CeO}_{2}$ and $\mathrm{Sb}_{2} \mathrm{O}_{3}$ and modifying additives $\mathrm{SrO}, \mathrm{MgO}$, and $\mathrm{CaO}$ for the crystallization were given.

It was found that providing a high level of strength of the developed glass-ceramic materials $(\alpha=$ $=62.5 \cdot 10^{-7} \mathrm{deg}^{-1}, H V=8.74 \mathrm{GPa}, K_{I C}=3.1 \mathrm{MPa} \cdot \mathrm{m}^{1 / 2}$ ) and light transmittance in the visible part of the spectrum 0.72 , is realized by fine volume crystallization of glass with the content of lithium disilicate $45 \mathrm{vol} \%$ and $\beta$-spodumene $5 \mathrm{vol} \%$. This fact allows them to be considered as promising in the development of lightweight transparent armor $\left(\rho=2.38 \mathrm{~g} / \mathrm{cm}^{3}\right)$, which is utilized under the influence of high-energy means of destruction with significant penetrating power.

\section{References}

[1] Huang S., Cao P., Wang C. et al.: J. Asian Ceram. Soc., 2013, 1, 46. https://doi.org/10.1016/j.jascer.2013.02.007

[2] Durschang B., Probst J., Thiel N. et al.: Pat. US 2015246843, Publ. Sept. 3, 2015.

[3] Khalilev V., Suzdal' N.: Glass Ceram., 2004, 61, 42. https://doi.org/10.1023/B:GLAC.0000026771.19312.6e [4] Khalilev V., Androkhanov A., Merkulov Yu. et al.: Pat. RU 2169712, Publ. Jun. 27, 2001. 
[5] Merkulov Yu.: Pat. RU 2176624, Publ. Dec. 10, 2001.

[6] Rudoi B.: Pat. US 4473653, Publ. Sept. 25, 1984.

[7] Darrant J., Thompson C.: Pat. GB 2379659, Publ. March 19, 2003.

[8] Budd M., Darrant J.: Pat. GB 2284655, Publ. Jun. 14, 1995.

[9] Beall G., Fu Q., Moore L. et al.: Pat. US 2015/0274581, Publ. Oct. 01, 2015.

[10] Grujicic M., Bell W., Pandurangan B.: Mat. Design, 2012, 34, 808. https://doi.org/10.1016/j.matdes.2011.07.007

[11] Crouch I. (Ed.): The Science of Armour Materials. Woodhead Publishing, Duxford 2016.

[12] Savvova O., Sobol Yu., Gryvtsova A. et al.: Visnyk Nats.

Techn. Univ. "KhPI", 2016, 22, 161.

[13] Bereznoi A.: Sitally i Photositally. Mashinostroenie, Moskva 1981.

Received: June 06, 2017 / Revised: June 15, 2017 / Accepted: September 03, 2017

\section{СКЛОКРИСТАЛІЧНІ МАТЕРІАЛИ НА ОСНОВІ ДИСИЛІКАТУ ЛІТІЮ: ДОСЯГНЕННЯ ТА ПЕРСПЕКТИВИ РОЗВИТКУ}

Анотація. Проаналізовано сучасний стан розробок $i$ перспективність використання склокристалічних матеріалів на основі дисилікату літію. Обгрунтовано вибір системи $\mathrm{R}_{2} \mathrm{O}$ $\mathrm{RO}-\mathrm{RO}_{2}-\mathrm{R}_{2} \mathrm{O}_{3}-\mathrm{P}_{2} \mathrm{O}_{5}-\mathrm{SiO}_{2}$ для модельних стекол. Досліджено структуру стекол після термооброблення у взаємозв'язку з їх фізико-хімічними властивостями. Розроблені літійсилікатні склокристалічні матеріали характеризуються високими експлуатаційними властивостями і можуть бути застосовані як прозора броня.

Ключові слова: склокераміка, літійсилікатні стекла, дисилікат літію, високоміцний, прозора броня. 